\title{
Waste treatment of remazol blue compounds based on ozonation/AOP in a bubble column reactor
}

\author{
Meidina Sekar Nadisti ${ }^{1}$, Nur Annisa ${ }^{1}$, Eva Fathul Karamah $^{1}$, Nelson Saksono ${ }^{1}$, and Setijo Bismo ${ }^{1, *}$ \\ ${ }^{1}$ Universitas Indonesia, Faculty of Engineering, Department of Chemical Engineering, Kampus UI Depok, Depok 16424, Indonesia
}

\begin{abstract}
Increased production in the textile industry has the potential to result in high dye waste water. Various conventional methods to handle with textile waste treatment have been done, but still considered not yet or less effective. The AOP technology (Advanced Oxidation Processes) applied in this research is a rapid degradation technology in textile wastes with advanced oxidation process through the formation of hydroxyl radical $(\mathrm{OH})$ which is considered to optimize the degradation process of textile dye waste. This study aims to evaluate the performance of ozonation methods and $\mathrm{AOP}\left(\mathrm{O}_{3} / \mathrm{UV} / \mathrm{H}_{2} \mathrm{O}_{2}\right)$ in dye degradation of textile wastewater containing remazol blue compounds. Both configuration methods used are optimized in several parameters such as waste flow rate, ozone voltage and $\mathrm{pH}$ to obtain maximum remazol blue degradation. From this study, the higher percentage to remazol blue degradation is $99.99 \%$, which is achieved by AOP method, with double air injection air flow rate of $10 \mathrm{~L} / \mathrm{min}$ and $0.25 \mathrm{~L} / \mathrm{min}$ liquid flow rate.
\end{abstract}

\section{Introduction}

Various methods for dealing with dye contamination prior to discharge into a body of water have been performed, such as coagulation, oxidation, and electrochemistry. However, such methods are considered inadequate to address the problem of dye contamination, since this method essentially simply addresses the state of wastewater containing a more concentrated pollutant [1]. Among the modern methods of waste prevention, there is a method of degradation with the AOPs which is a simple, fast, efficient and cheap alternative method [2]. The AOPs (Advanced Oxidation Processes) method has the main advantage of being able to degrade harmful compounds that can not decompose completely in waste through the oxidation process [3].

AOP technology is one or a combination of several processes such as ozone, hydrogen peroxide, UV rays, titanium oxide, phosphate and some other processes to produce $\mathrm{OH}$ radicals. $\mathrm{OH}$ radicals are an active species known to have a high oxidation potential of $2.8 \mathrm{~V}$ exceeding ozone that has a potential oxidation of only $2.07 \mathrm{~V}$ [4]. The combination of $\mathrm{O}_{3} / \mathrm{UV} / \mathrm{H}_{2} \mathrm{O}_{2}$ systems was chosen because it is more effective in destroying organic compounds than $\mathrm{O}_{3}$ or UV alone, and it is also more efficient to produce $\mathrm{OH}$ compared to $\mathrm{UV} / \mathrm{H}_{2} \mathrm{O}_{2}$ at the same oxidant concentration [3]. UV technology is shown to be synergistic with ozone $\left(\mathrm{O}_{3}\right)$ due to its ability to produce many active species such as $\bullet \mathrm{HO}, \cdot \mathrm{O}, \cdot \mathbf{H}$, and $\mathrm{H}_{2} \mathrm{O}_{2}$ which are powerful oxidizing agents. The AOP technique in this study is applied in a bubble column reactor because of the design advantage of the reactors, which has an excellent heat and mass transfer characteristics, meaning high heat and mass transfer coefficients. It also has little maintenance and low operating costs due to lack of moving parts and compactness [5]. Other than that, oxidation process in AOP will enhance the chemical reactions, causing oxidation processes such as removal, sterilization, reduction, and breaking of bonds or chemical reactions of ozone [6].

\section{Material and methods}

The reactor used in this study is the continuous bubble column reactor with multi injections. This reactor is made from pyrex glass, with specifications $190 \mathrm{~cm}$ height and $9 \mathrm{~cm}$ diameter. The reactor system is equipped with 3 dielectric discharge ozonators and a UV lamp. The configuration is shown in Figure 1.

This study is encountered first by testing the hydrodynamics of the bubble column reactor, using water as the liquid phase and air as the gas phase. This represents the column character and giving the general outlook about which range of variations should be done in the further study.

During the experiment, the optimal operating conditions achieved are at the time of processing using ozonation and AOP techniques, while the results of which are measured based on the percentage of waste degradation. In this study, the synthetic waste used was remazol blue compound as a textile and batik dye, with a concentration of $50 \mathrm{ppm}$. Meanwhile, the total volume of liquid used in multiple injection columns is $15 \mathrm{~L}$.

* Corresponding author: setijo.bismo@ui.ac.id 


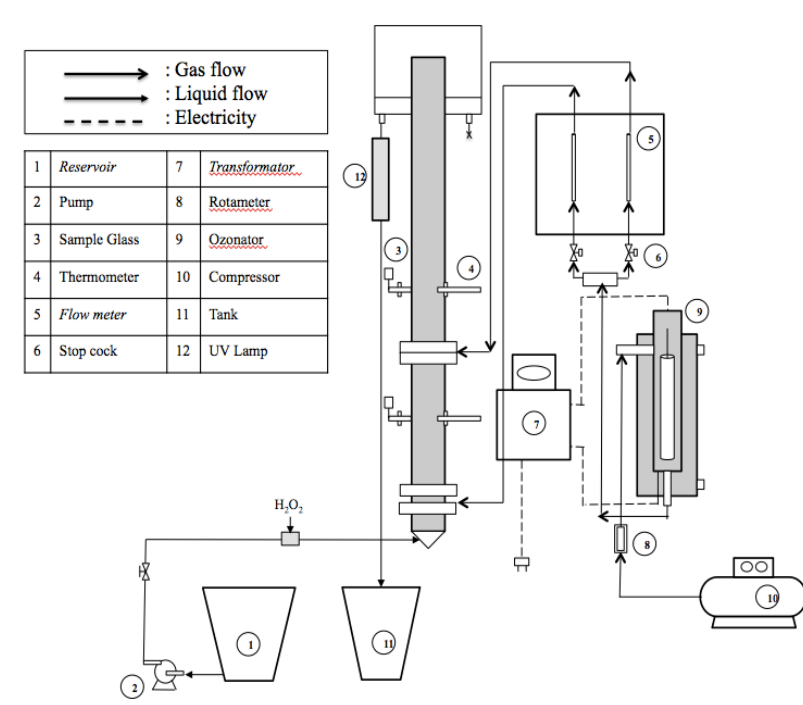

Fig. 1. The schematic of the AOP technique - bubble column reactor

\section{Results and discussion}

\subsection{Hydrodynamic testing}

Hydrodynamic test aims to determine the combination of the best reactor profiles that can be obtained from analysing the effect of voltage, air flow rate and liquid flow rate. It is hoped that hydrodynamic test of the reactor can produce a prospective ozonisation process.

\subsubsection{Voltage effect towards liquid flow rate}

In the circuit of reactor configuration in Figure 1, it can be seen that the pump is driven by a voltage regulated power supply. The voltage setting of the power supply is closely related to the change in the liquid flow rate of the waste that is pumped into the reactor. The purpose of knowing the voltage function of the liquid flow rate is to know the profile of the liquid flow rate to be used in this study.

From Figure 2 below it can be seen that the higher the voltage the higher the fluid flow rate. High residence time can be obtained if the liquid flow rate is low [6]. For this initial hydrodynamic test, the desired residence time is a maximum of one hour and a minimum of 30 minutes, so the variations are taken at 8,10 and 12 Volt.

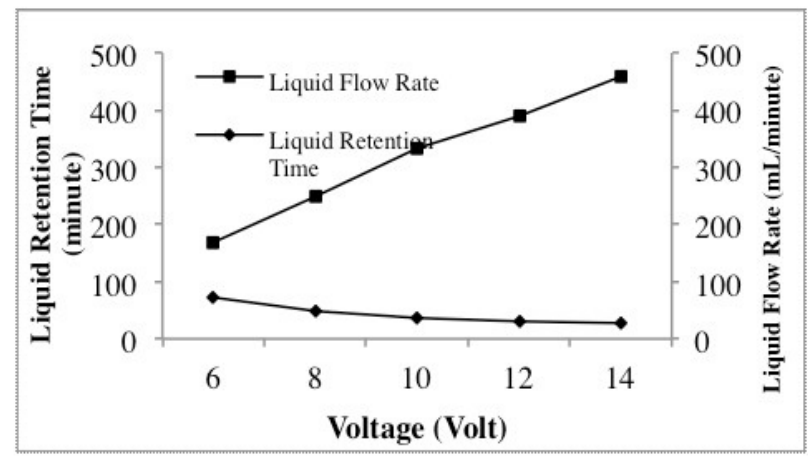

Fig. 2. The relationship between voltage and liquid retention time and liquid flow rate

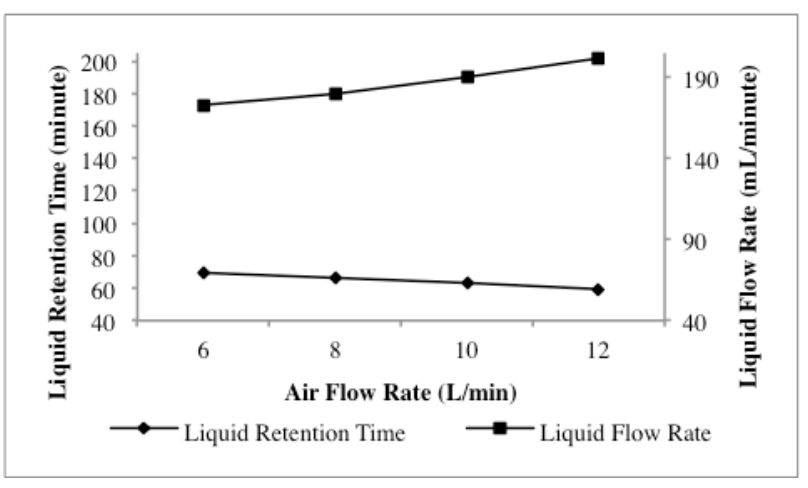

Fig. 3. The relationship between air flow rate and the liquid retention time and flow rate

\subsubsection{Air injection effect}

The purpose of this study is to know the effect of air injection towards liquid flow rate and liquid retention time. With liquid flow rate is set to be $0.33 \mathrm{~L} / \mathrm{min}$. Injection is done at the bottom of the column.

As can be seen in Figure 3, air injection has an effect on decreasing fluid residence time. Where the higher the gas flow rate, the smaller the fluid residence time. This is due to the higher air flow rate make the bubbles of gas formed increasing and the size becomes larger, thus pushing the fluid axially upward at a greater rate [6]. In this case, the fluid time to be inside the column becomes shorter.

In this test is also visually observed where with the greater air flow rate, the hold up gas is greater, thus increasing the contact surface area between the gas phase and liquid phase, so it is expected to have a bigger dissolved ozone. In this study, it is concluded that the smaller air flow rate make the higher the residence time of the liquid, while the greater the air flow rate make the higher surface area of the mass transfer. Thus, in this preliminary study, variations of air flow rates are taken at 8,10 , and $12 \mathrm{~L} / \mathrm{min}$.

\subsubsection{Multi injections effect}

The purpose of this study is to know the effect of multi injections towards the pressure drop across the column. $\mathrm{P}_{1}$ is the pressure in the top of the column, $\mathrm{P}_{2}$ is the pressure in the middle of the column and $\mathrm{P}_{3}$ is the pressure in the bottom of the column. The air is injected into both of the top $\left(\mathrm{Qg}_{1}\right)$ and bottom $\left(\mathrm{Qg}_{2}\right)$ of the column input of the column. With liquid flow rate is set to be $0.33 \mathrm{~L} / \mathrm{min}$.

From Figure 4 and Figure 5 as presented below, each shows a correlation between double injection (stratified) and or the impact of a pressure drop between P3 and P1 (at the bottom and top of the column), or between P3 and P2 ( at the bottom and center of the column), in such a way as to reduce the thrust force of the air flow during injection (that is, it facilitates the removal of fluid) which in turn can be easily achieved by homogenization. Furthermore, the homogenization can lead to better oxidation and waste removal processes along the column. 


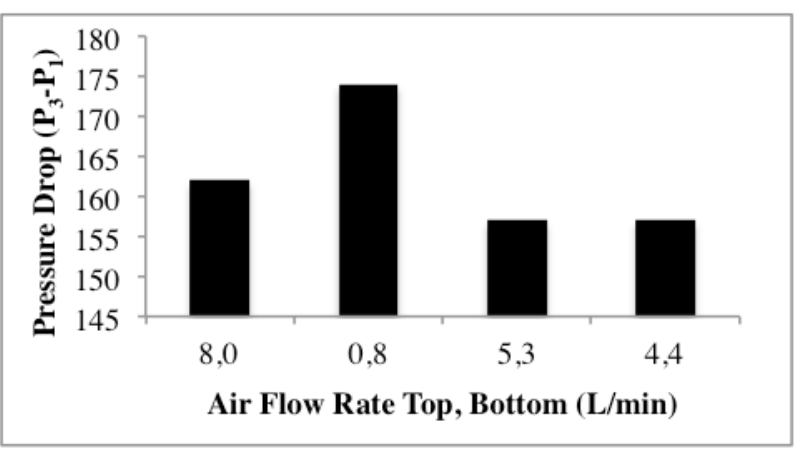

Fig. 4. The effect of double injection on the pressure drop within the top and the bottom of column $\left(\Delta \mathrm{P}_{1,3}\right)$.

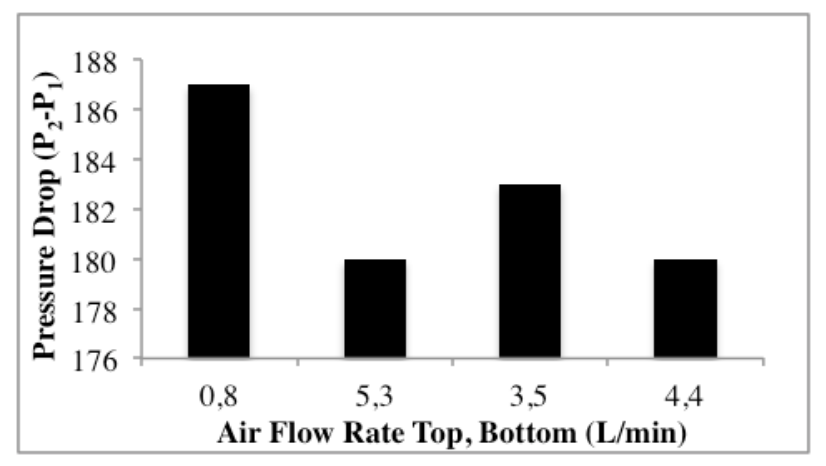

Fig. 5. The effect of double injection on the pressure drop within the top and the middle of column $\left(\Delta \mathrm{P}_{1,2}\right)$

From the hydrodynamic study, it can be seen that if the flow of gas (oxygen or air) is only injected through the bottom of the column $\left(\mathrm{Qg}_{2}\right)$, a smaller dissolved gas phase will be produced in the middle of the column to the top [6]. This may certainly occur because dissolved oxygen is a function of pressure. Using double injection, it can be seen in Figure 5 that $\Delta \mathrm{P}_{2,3}$ has decreased. If the pressure in $\mathrm{P}_{2}$ increases, the dissolved oxygen in that position also increases. With the above analysis, the next procedure chosen is double injection for degradation of remazol blue waste in variations of 8,10 and $12 \mathrm{~L} / \mathrm{min}$ in the hope of reducing the thrust in the lower column and increasing oxygen solubility in the middle and top of the column.

\subsection{Ozone productivity test}

The ozonator used in this research is tubular model ozonator similar to DBD reactor used by Winanti et al [7]. There are 3 micro ozonators used in this research, which is divided into 2 series. The first circuit consists of 2 micro ozonators, which is focused to inject the lower column. The second circuit consists of 1 micro ozonator, which is focused to inject the middle column. The ozone productivity test aims to determine the amount of ozone produced in the first and second ozonator circuits, so that the total productivity of ozone can be known. The test was performed by iodometric titration methods. These methods and reactions are according to previous research done by Birdsall et al. [8].

$$
\mathrm{I}_{2}+2 \mathrm{Na}_{2} \mathrm{~S}_{2} \mathrm{O}_{3} \rightarrow 2 \mathrm{NaI}+\mathrm{Na}_{2} \mathrm{~S}_{4} \mathrm{O}_{6}
$$

$$
\mathrm{O}_{3}+\mathrm{H}_{2} \mathrm{O}+2 \mathrm{Na}_{2} \mathrm{~S}_{2} \mathrm{O}_{3} \rightarrow 2 \mathrm{OH}^{-}+4 \mathrm{Na}^{+}+\mathrm{S}_{4} \mathrm{O}_{6}^{2-}+\mathrm{O}_{2}
$$

Ozone production is calculated by dividing the ozone moles number obtained from the titration with the contact time of ozone in KI solution. The contact time of ozone during oxidizing $\mathrm{KI}$ is carried out for 5 minutes. Based on the calculations, ozone production is obtained with each ozonator configuration as shown in Table 1.

Table 1. Ozonator Productivity Result

\begin{tabular}{|c|c|c|c|}
\hline $\begin{array}{c}\text { Air Flow } \\
\text { Rate } \\
\text { (L/min) }\end{array}$ & $\begin{array}{c}\text { Ozonator 1 } \\
\text { Productivity } \\
\text { (mg/hour) }\end{array}$ & $\begin{array}{c}\text { Ozonator 2 } \\
\text { Productivity } \\
\text { (mg/hour) }\end{array}$ & $\begin{array}{c}\text { Total } \\
\text { Productivity } \\
\text { (mg/hour) }\end{array}$ \\
\hline 5 & 213.50 & 380.16 & 593.66 \\
\hline 7.5 & 293.76 & 480.96 & 774.72 \\
\hline 10 & 374.016 & 581.76 & 955.78 \\
\hline Average & 293.76 & 480.96 & 774.72 \\
\hline
\end{tabular}

Based on Table 1 above, there appears an increase in ozone production along with the addition of air flow rate and the amount of ozonator used. The average ozone production for the ozonator circuit 1 is $293.76 \mathrm{mg} / \mathrm{h}$ and for the ozonator circuit 2 is $480.96 \mathrm{mg} / \mathrm{h}$.

\subsection{Radical Hydroxyl Quantification Test}

The hydroxyl radical analysis was performed by permanganometry titration method. In the process of hydroxyl radical quantification test, the solution used is aquades as a substitute for the remazol blue dye waste water. Since no compounds can be oxidized, the formed hydroxyl radicals tend to react with each other and then form hydrogen peroxide $\left(\mathrm{H}_{2} \mathrm{O}_{2}\right)$. The oxidation of $\mathrm{H}_{2} \mathrm{O}_{2}$ by $\mathrm{KMnO} 4$ follows the following reduction-oxidation principal and formed in the reaction below:

$$
\begin{aligned}
& 5 \mathrm{H}_{2} \mathrm{O}_{2}+2 \mathrm{KMnO}_{4}+3 \mathrm{H}_{2} \mathrm{SO}_{4} \longrightarrow 2 \mathrm{O}_{2}+2 \mathrm{MnSO}_{4}+ \\
& \mathrm{K}_{2} \mathrm{SO}_{4}+8 \mathrm{H}_{2} \mathrm{O}
\end{aligned}
$$

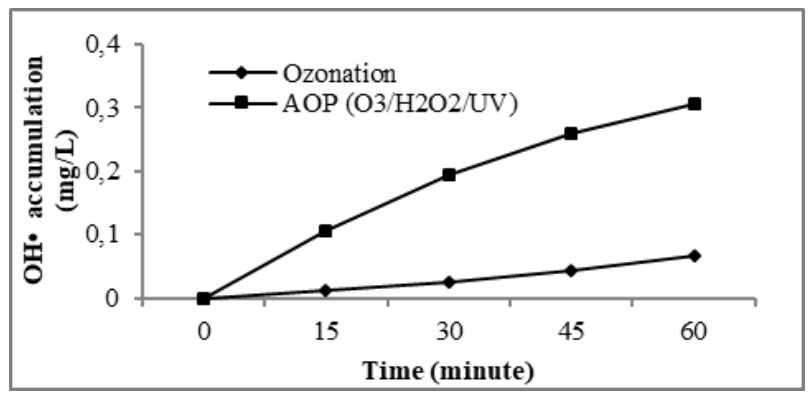

Fig. 6. Quantity of $\mathrm{OH}$ radicals in ozonation and $\mathrm{AOP}(\mathrm{V}=15$ $\mathrm{L}, \mathrm{Qg}_{1}=4 \mathrm{~L} / \mathrm{min}, \mathrm{Qg}_{2}=6 \mathrm{~L} / \mathrm{min}, \mathrm{Q}_{\mathrm{w}}=0.25 \mathrm{~L} / \mathrm{min}$ )

The tests were performed on optimum degradation of remazol blue, at initial $\mathrm{pH}$ of waste 10 , lower column flow rate $\left(\mathrm{Qg}_{2}\right) 6 \mathrm{~L} / \mathrm{min}$, top column flow rate $\left(\mathrm{Qg}_{1}\right) 4$ $\mathrm{L} / \mathrm{min}$ and $0.25 \mathrm{~L} / \mathrm{min}$ liquid flow rate.

In Figure 6, it appears that in both methods the amount of $\mathrm{OH}$ radicals generated increases with time. The $\mathrm{pH}$ used here is an alkaline $\mathrm{pH}$, as in the study by [9], that with an increasingly alkaline $\mathrm{pH}$ the $\mathrm{OH}$ radicals 
formed also more and more. At an alkaline atmosphere, ozone is induced by the presence of hydroxide ions in solution, thus decomposing more quickly into $\mathrm{OH}$ radicals [9]. The more hydroxide ions are formed so the number of $\mathrm{OH}$ radicals increase.

$\mathrm{OH}$ radicals generated on the combination of AOP $\left(\mathrm{O}_{3} / \mathrm{H}_{2} \mathrm{O}_{2} / \mathrm{UV}\right)$ are more than a single ozonation method. This is because the $\mathrm{OH}$ radicals in the combination of AOP $\left(\mathrm{O}_{3} / \mathrm{H}_{2} \mathrm{O}_{2} / \mathrm{UV}\right)$ formed from several sources, namely the normal decomposition of ozone, $\mathrm{H}_{2} \mathrm{O}_{2}$ decomposition and the presence of light energy (UV). Besides, the AOP configuration may trigger some active species such as $\mathrm{HO} \bullet, \mathrm{O} \bullet$, and $\mathrm{H} \bullet[11]$.

\subsection{Degradation of Remazol Blue by ozonation}

In determining the optimum conditions of remazol blue degradation, several things including variables that have been studied in the initial study of hydrodynamics, such as air flow rate (function of ozone dosage), water flow rate and injection system are varied. The three variations based on this initial hydrodynamic study is carried out by a single ozonisation method. After getting the optimum condition on the above three variations, then used the AOP system.

\subsubsection{Effect of air flow rate (1 Injection point) on remazol blue degradation}

The effect of air flow rate, which is a function of ozone production, to dye degradation of remazol blue is evaluated within this chapter. Air flows respectively from the two input of the ozonator circuit (ozonator circuit 1 and ozonator circuit 2) with a total flow of 8 $\mathrm{L} / \mathrm{min}, 10 \mathrm{~L} / \mathrm{min}$ and $12 \mathrm{~L} / \mathrm{min}$, then streams are united and injected into the lower column $\left(\mathrm{Qg}_{2}\right)$. In the initial study of hydrodynamics it is known that the smaller the air flow rate the fluid residence time is increased, while the greater the air flow rate make the surface area of the liquid-gas contact increasing. Based on this fact, the three air flow rate points are chosen to determine which air flow rate produces the best remazol blue degradation percentage.

The operating conditions used were the initial concentration of waste of $45 \mathrm{ppm}$, the water flow rate of $0.332 \mathrm{~L} / \mathrm{min}$, the volume of waste $15 \mathrm{~L}$, the initial $\mathrm{pH}$ of waste 10 and the degradation process for 60 minutes. The test is done by injecting both ozonator circuits to the lower column $\left(\mathrm{Qg}_{2}\right)$. The effect of air flow rate on the percentage of remazol blue degradation is presented in Figure 7.

Based on Figure 7 below, the $12 \mathrm{~L} / \mathrm{min}$ air flow rate has the lowest degradation results, this is due to the too high air flow rate, which causes the fluid flow rate to increase and the residence time of the small liquid. As for the air flow rate of $8 \mathrm{~L} / \mathrm{min}$ and $10 \mathrm{~L} / \mathrm{min}$ has a quite difference of the final concentration, which is $0.04 \mathrm{ppm}$. For the $8 \mathrm{~L} / \mathrm{min}$ air flow rate, although it can degrade with the results below the quality standard, the percentage is still below the $10 \mathrm{~L} / \mathrm{min}$ air flow rate. This is because the $10 \mathrm{~L} / \mathrm{min}$ air flow rate has a strong influence in increasing the liquid-gas contact area compared to the $8 \mathrm{~L} / \mathrm{min}$ air flow rate. Therefore, in this test, the total air flow of $10 \mathrm{~L} / \mathrm{min}$ is chosen to further section.

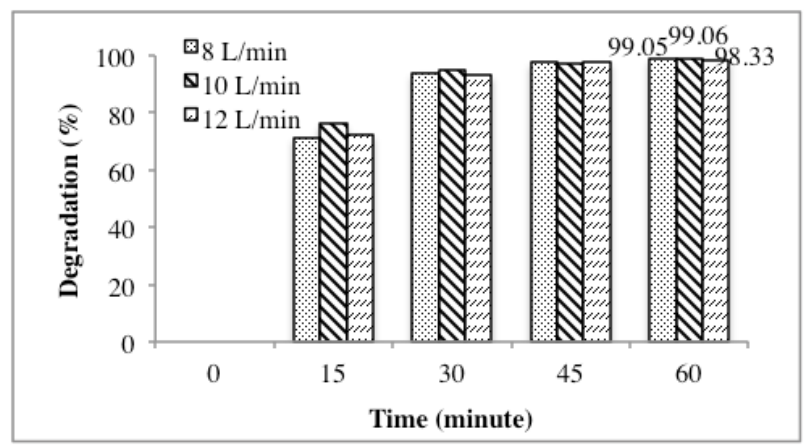

Fig. 7. Effect of air flow rate at 1 point of injection to remazol blue degradation percentage $\left(\mathrm{Co}=48 \mathrm{ppm}, \mathrm{V}=15 \mathrm{~L}, \mathrm{Q}_{\mathrm{w}}=10\right.$ Volt $=332 \mathrm{~mL} / \mathrm{min}, \mathrm{pH}_{\mathrm{oo}}=10$ )

\subsubsection{Effect of Air Flow Rate (2 Injection Point) on Remazol Blue Degradation}

At this stage, the effect of air flow rate at 2 point of injections for remazol blue degradation is tested. In the previous test, the total optimum air flow rate is $10 \mathrm{~L} / \mathrm{min}$, equal to ozone production of $593.66 \mathrm{mg} / \mathrm{h}$. From the total $10 \mathrm{~L} / \mathrm{min}$ air flow rate, $\mathrm{Qg}_{1}$ (middle column injections) and $\mathrm{Qg}_{2}$ (lower column injections) are varied to remazol blue degradation.

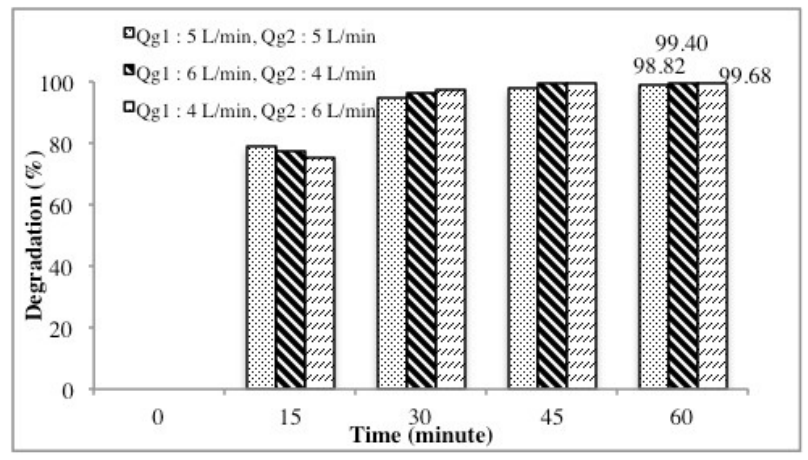

Fig. 8. Effect of air flow rate at 2 point of injection to remazol blue degradation percentage $\left(\mathrm{Co}=48 \mathrm{ppm}, \mathrm{V}=15 \mathrm{~L}, \mathrm{Q}_{\mathrm{w}}=10\right.$ Volt $=332 \mathrm{~mL} / \mathrm{min}, \mathrm{pH}_{\mathrm{o}}=10, \Sigma \mathrm{Qg}=10 \mathrm{~L} / \mathrm{min}$ )

Based on Figure 8 , it is seen that the largest percentage of remazol blue degradation present in the series $\mathrm{Qg}_{1}=4 \mathrm{~L} / \mathrm{min}$ and $\mathrm{Qg}_{2}=6 \mathrm{~L} / \mathrm{min}$. This is because of the influence of good thrust and high ozone production. Configuration of higher air flow rate placed in the lower column facilitates the rising fluid upward so that homogenization in the middle and top columns can be achieved better. As discussed in the initial study of hydrodynamics, the ozone solubility in the upper column is difficult to homogenize, and this is also evidenced by the researcher's visual (the upper column colour is more transparent than the bottom column). In addition to the influence of the thrust, the $\mathrm{Qg}_{1}=4 \mathrm{~L} / \mathrm{min}$ and $\mathrm{Qg}_{2}=6$ $\mathrm{L} /$ min configurations have the highest ozone production, resulting in the highest degradation (the amount of ozone 
decomposed into $\mathrm{OH}$ radicals to degrade the remazol blue). Therefore, in this test, the air flow rate optimation point was taken at $\mathrm{Qg}_{1}=4 \mathrm{~L} / \mathrm{min}$ and $\mathrm{Qg}_{2}=6 \mathrm{~L} / \mathrm{min}$.

\subsubsection{Effect of liquid flow rate on remazol blue Degradation}

At this stage, the researchers evaluate the effect of liquid flow rate on remazol blue degradation. As is known in the initial study of hydrodynamics, that the smaller the flow rate of liquid, the higher the residence time of the liquid.

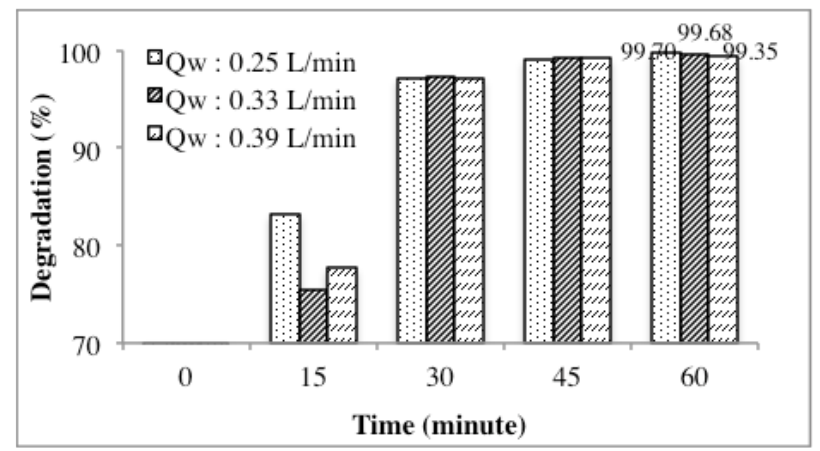

Fig. 9. Effect of liquid flow rate on remazol blue degradation percentage $\left(\mathrm{Co}=48 \mathrm{ppm}, \mathrm{V}=15 \mathrm{~L}, \mathrm{Qg}_{1}=4 \mathrm{~L} / \mathrm{min}, \mathrm{Qg}_{2}=6\right.$ $\mathrm{L} / \mathrm{min}, \mathrm{pH}_{\mathrm{o}}=10$ )

It can be seen in Figure 9 that the smaller the liquid flow rate, the higher the percentage of degradation obtained. This is because if the residence time is high, the longer the reaction time of remazol blue degradation, the longer the time to decompose the compounds into active radical compounds so that the quantity of radical compounds becomes more. Therefore, in this test is selected $\mathrm{Q}_{\mathrm{w}}=0.25 \mathrm{~L} / \mathrm{min}$ as the optimum point on the variation of liquid flow rate.

\subsection{Degradation of remazol blue by AOP $\left(\mathrm{O}_{3} / \mathrm{H}_{2} \mathrm{O}_{2} / \mathrm{UV}\right)$}

After obtaining the optimum conditions for air flow rate, liquid flow rate and injections configurations, the next step is to evaluate remazol blue degradation using AOP $\left(\mathrm{O}_{3} / \mathrm{H}_{2} \mathrm{O}_{2} / \mathrm{UV}\right)$ method. Evaluation of the effect of $\mathrm{pH}$ was done with optimized variables on single ozonation; $0.25 \mathrm{~L} / \mathrm{min}$ liquid flow rate, air flow rate distributed at 2 injection, with $\mathrm{Qg}_{1}=4 \mathrm{~L} / \mathrm{min}$ and $\mathrm{Qg}_{2}=6 \mathrm{~L} / \mathrm{min}$, and ozone dose $601.88 \mathrm{mg} / \mathrm{h}$. The result of remazol blue degradation percentage with $\mathrm{pH}$ variation is shown in Figure 10.

Based on such Figure 10, it can be seen that a trend where degradation percentage increases as the initial $\mathrm{pH}$ value increases. In the base atmosphere, ozone is quickly decompose into $\mathrm{OH}$ radicals, resulting in a higher percentage of degradation than neutral atmosphere. This is also indicated by the result of quantification of hydroxyl radical wherein the AOP method produces more hydroxyl radical than single ozonation, and this can be confirmed by AOP degradation test result which reach $99.99 \%$ at optimum $\mathrm{pH}$.

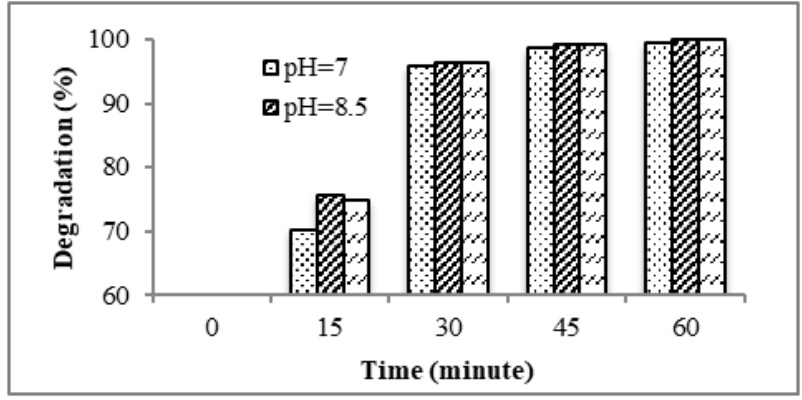

Fig.10. Effect of $\mathrm{pH}$ on remazol blue degradation percentage $\left(\mathrm{Co}=48 \mathrm{ppm}, \mathrm{V}=15 \mathrm{~L}, \mathrm{Qg}_{1}=4 \mathrm{~L} / \mathrm{min}, \mathrm{Qg}_{2}=6 \mathrm{~L} / \mathrm{min}, \mathrm{Q}_{\mathrm{w}}=\right.$ $0.25 \mathrm{~L} / \mathrm{min})$

Table 2. Method's Result Comparation

\begin{tabular}{|c|c|c|c|c|}
\hline Method & $\begin{array}{c}\text { Degradation } \\
(\mathbf{\%})\end{array}$ & $\begin{array}{c}\text { End } \\
\text { Concentration } \\
(\mathbf{p p m})\end{array}$ & $\begin{array}{c}\mathbf{p H} \\
\mathbf{( t = 0 )}\end{array}$ & $\begin{array}{c}\mathbf{p H} \\
\mathbf{( t = 6 0} \\
\mathbf{)}\end{array}$ \\
\hline Ozonation & 99.7 & 0.14 & 10 & 4.1 \\
\hline AOP & 99.99 & 0.0067 & 10 & 4.11 \\
\hline
\end{tabular}

Based on the Table 2 above, it can be seen that the difference of remazol blue degradation between single ozonation method and AOP is quite small. Ozone itself is a powerful oxidizing agent capable of degrading organic pollutants due to its high oxidation, as evidenced by the tests in the previous subsections, even with single ozonation has already reached a percentage degradation above 99\%. However, when viewed from the final concentration, the AOP method can reach $0.0067 \mathrm{ppm}$ and is believed to maintain the quality of waste quality standards constantly than the ozonation method, as reffered to [12].

Another change that occurs during the ongoing degradation process is the change in the end $\mathrm{pH}$. Significant $\mathrm{pH}$ reduction in both systems is due to the formation of compounds between the acidic ozonation products such as aldehydes and carboxylates which are ionized in water. This is consistent with the Arhenius and Bronsted theories, where more acid is produced the concentration of $\mathrm{H}^{+}$in the solution is higher so that the $\mathrm{pH}$ decreases.

Higher percentage results of AOP degradation can be achieved due to several factors, mainly due to the effect of adding $\mathrm{H}_{2} \mathrm{O}_{2}$ and UV doses to the system. As explained before, that continuous UV use can decompose $\mathrm{H}_{2} \mathrm{O}_{2}$ so that the quantity of $\square$ formed into $\mathrm{OH} \bullet \mathrm{OH} \bullet$ increase. This is supported by the quantity of $\mathrm{OH}$ radicals in the AOP system more than in a single ozonation system.

In addition, in AOP systems it is possible that the resulting $\mathrm{OH}, \mathrm{H}_{2}, \mathrm{O}_{2}$, and $\mathrm{H}_{2} \mathrm{O}_{2}$ species also increase with time so that the remazol blue compounds can be degraded into intermediate compounds.

\section{Conclusion}

From this study, it can be seen that both ozonation and AOP $\left(\mathrm{O}_{3} / \mathrm{H}_{2} \mathrm{O}_{2} / \mathrm{UV}\right)$ were able to achieve the quality standard or the desired quality standard based on the 
Ministry of Environment of Indonesia. The AOP is also believed to be the best choice to maintain quality standard concentrations of product are below quality standards. A higher percentage of degradation is achieved at a lower liquid flow rate, sufficient airflow rate distributed in double injection, with a higher airflow rate composition at the bottom of the bubble column. The optimum operating conditions for this study is achieved with double air injection system, air flow rate of $10 \mathrm{~L} / \mathrm{min}$ and liquid flow rate of $0.25 \mathrm{~L} / \mathrm{min}$.

This research have been conducted thanks to the "PITTA Grant" (Hibah Publikasi Internasional Terindeks Tugas Akhir Mahasiswa Universitas Indonesia) 2018, which was organized by the Directorate of Research and Community Service (DRPM) - Universitas Indonesia. The authors state that there is no competing interest or conflict of financial interests.

\section{References}

1. T. Ahmed, E. Khaled, R. Helles. S. Elimination of Remazole Blue-B by Advanced Oxidation Methods. J. of Al Azhar University. Vol. 8, 55-64 (2006)

2. G. Boczkaj, A. Fernandes. Wastewater treatment by means of Advanced Oxidation Processes at basic pH conditions: A review. Chem. Eng. J. (2017)

3. R. Munter. Advanced Oxidation Processes Current Status And Prospects. Proc. Estonian Acad. Sci. Chem. 50 (2) 59-80 (2001)

4. S. Khrisnan, H. Rawindran, C. M. Sinnathambi, J W Lim. Comparison of various advanced oxidation processes in remediation of industrial wastewater laden recalcitrant pollutants. IOP Conf. Ser: Mater. Sci. Eng. 206012089 (2016)

5. N. Kantarci, F. Borak, K.O Ulgen, 2005, Bubble column reactors. Review, Process Biochemistry, 40, 2263- 2283, DOI: 10.1016/j.procbio.2004.10.004

6. Dianursanti. Uji Hidrodinamika Kolom Aerasi Sistem injeksi Berganda Untuk Pengolahan Senyawa Organotoksik Dalam Limbah Cair industri. Depok : Universitas Indonesia (2000)

7. Winanti, W.S., Purwanto, W.W., Bismo, S., Decomposition of Carbon Dioxide in the Threepass Flow Dielectric Barrier Discharge Plasma Reactor. IJTech. 5(1), 51 (2014)

8. C. M. Birdsall, A. C. Jenkins, and E. Spadinger. Iodometric determination of ozone. Anal.

Chem. 24, 662-664. (1952)

9. P. A. Nurcahyani. Degradasi Zat Warna Blue KN$R$ pada Limbah Industri Batik Melalui Proses Oksidasi Lanjut Menggunakan Kombinasi Teknik Ozonasi dan Kavitasi Hidrodinamika. Depok: Universitas Indonesia (2015)

10. F. J. Beltran. Ozone Reaction Kinetics for Water and Wastewater System. UK: CRC Press (2003)

11. M. Antonopoulou, E. Evgenidou, D. Lambropoulou and I. Konstantinou. A review on advanced oxidation processes for the removal of taste and odor compounds from aqueous media. Water Res. 53 215-34 (2014)

12. Kementerian Lingkungan Hidup. Peraturan Menteri Lingkungan Hidup Republik Indonesia Nomor 5 Tahun 2014 Tentang Baku Mutu Air Limbah (2014) 